\title{
The Legal Enforceability of Articles 8.2 and 5.3 of the wHO Framework Convention on Tobacco Control: The Case of the Netherlands
}

\author{
Gohar Karapetian \\ University of Groningen \\ g.karapetian@rug.nl \\ Brigit Toebes \\ University of Groningen \\ b.c.a.toebes@rug.nl
}

\begin{abstract}
Since 2005, the WHo FCTC is binding on the Netherlands. Since that time, the Dutch courts have addressed Articles 8.2 and 5.3 FCTC on three occasions. In this article, we review these three cases in order to analyze the legal enforceability of Articles 8.2 and 5.3 FCTC in the Netherlands. Special attention is paid to the role the guidelines and recommendations adopted by the Conference of the Parties played in these cases. We observe that the legal enforceability of both articles depends on the specific circumstances of the case. We argue that the Dutch courts should have given more careful consideration to the FCTC guidelines and recommendations.
\end{abstract}

\section{Keywords}

Tobacco Industry - FCTC 5.3 - FCTC 8.2 - legal enforceability - litigation - the Netherlands

\footnotetext{
* PhD Candidate University of Groningen.
}

** Professor University of Groningen. 
Overview of Dutch Case Law Pertaining to Articles 8.2 and 5.3 FCTC

\begin{tabular}{|c|c|c|}
\hline Case & Applicable law & Decision \\
\hline CAN I v. the State & $\begin{array}{l}\text { Dutch Tobacco Act } 2008 \\
\text { Dutch Tobacco Decree } 2011 \\
\text { Article } 8.2 \text { FCTC }\end{array}$ & $\begin{array}{l}\text { National decree exempting small } \\
\text { cafes from the total smoking ban is } \\
\text { void; violation of Article } 8.2 \text { FCTC }\end{array}$ \\
\hline CAN II v. the State & $\begin{array}{l}\text { Dutch Tobacco Decree } 2015 \\
\text { Article } 8.2 \text { FCTC }\end{array}$ & $\begin{array}{l}\text { Article } 8.2 \text { FCTC is not legally } \\
\text { enforceable in the concerning } \\
\text { circumstances }\end{array}$ \\
\hline $\begin{array}{l}\text { Youth Smoking } \\
\text { Prevention } \\
\text { Foundation v. the }\end{array}$ & $\begin{array}{l}\text { Article } 5.3 \text { FСтс, right to life } \\
\text { and health, due diligence }\end{array}$ & $\begin{array}{l}\text { Article } 5 \cdot 3 \text { FCTC is not legally } \\
\text { enforceable in the concerning } \\
\text { circumstances. }\end{array}$ \\
\hline State & & $\begin{array}{l}\text { The judgment, however, entailed } \\
\text { policy change by the Ministry of } \\
\text { Health, Welfare and Sport }\end{array}$ \\
\hline
\end{tabular}

\section{Introduction}

In three recent cases before Dutch courts, civil society organizations held the Dutch government accountable for violating the wHo Framework Convention on Tobacco Control (FCTC). ${ }^{1}$ While the judgments by the courts did not all lead to a violation of the FСTC, this body of case law sets an interesting trend, since in the Dutch setting the FстC is directly applied and enforced before the Dutch courts. In one case, human rights standards also played an important role.

Due to the Dutch moderate incorporist system, treaties automatically form part of the Dutch legal order after ratification. In addition, contrary to states with a transformist system, the only requirement for international provisions in the Dutch domestic order to be judicially enforceable is that they should have direct effect according to Article 94 of the Dutch Constitution. ${ }^{2}$

12003 WHO Framework Convention on Tobacco Control (adopted 21 May 2003; entered into force 27 February 2005), UNTS 2302: 166.

2 Article 94 of the Dutch Constitution reads: 'Statutory regulations in force within the Kingdom shall not be applicable if such application is in conflict with provisions of treaties or of resolutions by international institutions that are binding on all persons; The Constitution of the Kingdom of the Netherlands, art. 94, available at: https://www.rechtspraak.nl/Site CollectionDocuments/Constitution-NL.pdf, accessed 20 December 2017. 
According to settled Dutch case law, direct effect in the Dutch domestic order means that the treaty provision concerned should be sufficiently precise and unconditional. ${ }^{3}$

Given the direct applicability, Dutch legal practice provides an interesting testing ground for assessing the domestic applicability of the FCTC. It complements the increasing worldwide reliance on the FCTC in courts ${ }^{4}$ and creates a worthwhile precedent for other FCTC State Parties. To contribute to the analysis of this global trend, we examine recent Dutch case law in relation to Articles 8.2 and 5.3 FCTC.

In order to clarify the FCTC provisions, the governing body of the FCTC, the Conference of the Parties (COP),$^{5}$ has clarified certain provisions of the Convention through the adoption of a set of guidelines, including in relation to Articles 8.2 and 5.3. The guidelines for Articles 8.2 and 5.3 were adopted unanimously by the COP and include several recommendations for State Parties on

3 See for instance: De Staat der Nederlanden (Ministerie van Volksgezondheid, Welzijn en Sport) v. Nederlandse Nietrokersvereniging CAN (Club Actieve Nietrokers), ECLI:NL:HR:2014:2928 (Supreme Court of the Netherlands, 2014), paras. 3.5.2-3.5.3 (in Dutch); unofficial English translation can be found here: https:/www.tobaccocontrollaws.org/litigation/decisions/ nl-20141010-dutch-association-of-can-v.-ne, accessed 20 December 2017 (hereinafter CAN I $v$. the State $[s c])$.

4 See for instance: Guatemala Chamber of Commerce v. Guatemala, Docket 2158-2009 (Constitutional Court of the Republic of Guatemala 2010), https://www.tobaccocontrollaws.org/ litigation/decisions/gt-20100216-guatemala-chamber-of-commerce-, accessed 20 December 2017; Caceres Corralesv. Colombia, Judgment C-830/10 (Constitutional Court of Colombia 2010), https://www.tobaccocontrollaws.org/litigation/decisions/co-20101020-caceres-corrales -v.-colombia, accessed 20 December 2017; British American Tobacco South Africa (Pty) Ltd. v Minister of Health, Case No. 463/2011, [2012] ZASCA 107; [2012] 3 All SA 593 (Supreme Court of Appeal of South Africa 2012), http://www.saflii.org/za/cases/ZASCA/2012/107.html, accessed 20 December 2017; British American Tobacco Colombia v. Coljuegos, Locator No. 20141200058571 (Coljuegos 2014), https://www.tobaccocontrollaws.org/litigation/decisions/co-20140212-bat ---colombia-v.-coljuegos, accessed 20 December 2017; Rodriguez Robles \& Espinosa on behalf of British American Tobacco Panama, s.A v. the Ministry of Health, Docket No. 192-11 (Supreme Court of Justice of Panama 2014), https://www.tobaccocontrollaws.org/litigation/decisions/ pa-20140528-british-american-tobacco-panam, accessed 20 December 2017; Philip Morris Brands SARL v. Secretary of State for Health (UK), Case C-547/14, ECLI:EU:C:2016:325 (Court of Justice of the European Union 2016); British American Tobacco United Kingdom v. Secretary of State for Health, [2016] EWHC 1169 (High Court of Justice, Queen's Bench Division, Administrative Court 2016).

5 Article 23 FCTC establishes the Conference of the Parties (COP). By virtue of Article 23.5 FCTC the COP 'shall keep under regular review the implementation of the Convention and take the decisions necessary to promote its effective implementation and may adopt protocols, annexes and amendments to the Convention, in accordance with Articles 28, 29 and 33'. 
how to fulfill their FCTC obligations. ${ }^{6}$ Therefore, in this contribution we also scrutinize how the Dutch courts have assessed the relevant FCTC guidelines and recommendations.

\section{Article 8.2 FCTC in the Netherlands: CAN I and CAN II}

\section{The First caN Case: Exemption of the Total Smoking Ban in Small Cafes; Article 8.2 Legally Enforceable}

In July 2008, an amendment to the Dutch Tobacco Act was adopted, according to which hotels, restaurants and cafes had to be smoke free. ${ }^{7}$ Exactly three years later, in 2011, a new decree exempted small cafes (less than 70 square meters) from the total smoking ban of 2008..$^{8}$ In 2014, a Dutch public health NGO, the 'Clean Air Nederland' (CAN), sued the Dutch government and claimed that the exemption of July 2011 constituted a violation of Article 8.2 FCTC. ${ }^{9}$ The Article obliges State Parties to adopt measures offering protection from exposure to tobacco smoke in indoor workplaces, public transport, indoor public places and where appropriate, other public places.

Two questions played a key role in the case: firstly, whether Article 8.2 FCTC has direct effect in light of Article 94 of the Dutch Constitution; and secondly, if so, whether the decree of July 2011 constituted a breach of Article 8.2 FCTC.

6 Conference of the Parties to the wHo Framework Convention on Tobacco Control, 'Guidelines for Implementation of Article 5.3: Protection of Public Health Policies with Respect to Tobacco Control from Commercial and Other Vested Interests of the Tobacco Industry', Doc. FCTC/COP3(7), Third Session, 17-22 November 2008, http://www.who.int/fctc/treaty _instruments/Guidelines_Article_5_3_English.pdf?ua=1, accessed 20 December 2017; Conference of the Parties to the wHo Framework Convention on Tobacco Control, 'Elaboration of Guidelines for Implementation of the Convention (Decision FCTC/COP1(15)) - Article 8: Protection from Exposure to Tobacco Smoke', Doc. A/FCTC/COP/2/7, Second Session, 26 April 2007, http://apps.who.int/gb/fctc/PDF/cop2/FCTC_COP2_7-en.pdf, accessed 20 December 2017 .

7 CAN I v. the State [sc], supra note 3, para. 3.1.

8 cAN I v. the State [sc], supra note 3, para. 3.1.

9 Article 8.2 FCTC reads: 'Each Party shall adopt and implement in areas of existing national jurisdiction as determined by national law and actively promote at other jurisdictional levels the adoption and implementation of effective legislative, executive, administrative and/or other measures, providing for protection from exposure to tobacco smoke in indoor workplaces, public transport, indoor public places and, as appropriate, other public places'. 
Both the Court of Appeal ${ }^{10}$ and the Dutch Supreme Court ${ }^{11}$ answered these questions affirmatively. They first stated that direct effect of treaty provisions can be implemented if the standards and results of a specific treaty provision are sufficiently clear and unconditional:

3.5.2 The important question is whether the text is sufficiently explicit and precise so as to be applied unconditionally as an objective right within the judicial system (see Hoge Raad 1 April 2010, ECLI:NL:H R:2011:BP3044, NJ 2011, 354).

3.5.3 If the resulting change to be achieved in the national judicial system on the grounds of the treaty provision is implicit and described in sufficiently precise terms, the mere fact that the regulator or the government is free to decide on matters of policy concerning the proposed measures in regard to the result realization does not prevent the provision from having direct effect. Whether such an impact exists depends on the question whether the provision can function as an objective right in the context concerned, whereby it is invoked. In contrast to what the State argues, the mere existence of freedom to determine one's choice or policy does not imply that there is no direct effect (produced) (see Hoge Raad 9 April 2010, ECLI:NL:HR:2010:BK4549, NJ 2010,388 (SGP)).12

Article 8.2 FCTC is, according to the Court of Appeal, clear and concrete with regard to the result it aims to realize on the national level, i.e. effective protection against exposure to tobacco smoke in the prescribed places. ${ }^{13}$ As such, both the Court of Appeal and the Dutch Supreme Court were of the opinion that Article 8.2 FCTC is sufficiently clear for adjudication before a court of law.

The Court of Appeal has decided that Art. 8 par. 2 of the who Framework Convention imposes an obligation to offer accessible effective protection against exposure to tobacco smoke and make it visible in places indicated in the article paragraph, whereby public buildings ('indoor public places') include small cafes. The text of this provision, as well as the objective of

\footnotetext{
$10 \quad$ Nederlandse Nietrokersvereniging CAN (Club Actieve Nietrokers) v. De Staat der Nederlanden (Ministerie van Volksgezondheid, Welzijn en Sport), ECLI:NL:GHDHA:2013:BZ4871 (Hague Court of Appeal 2013) (available only in Dutch).

11 CAN I v. the State [sc], supra note 3.

12 CAN I v. the State [sc], supra note 3, para. 3.5.2.

13 CAN I v. the State [sc], supra note 3, 3.5-3.6.
} 
the Treaty, implies that this protection - i.e.: prevention of health hazards and death resulting from being exposed to tobacco smoke - is valid for everyone who enters or wants to enter such places. ${ }^{14}$

Both courts continued by stating that the imposed obligation of Article 8.2 FCTC is to offer effective protection against the exposure of tobacco smoke in the indicated places, such as public buildings and indoor public places, which include small cafes of 70 square meters. Consequently, according to the courts, in the circumstances of this case the exemption decree of July 2011 was in conflict with Article 8.2 FCTC. By virtue of Article 94 of the Dutch Constitution, the international provision (i.e. Article 8.2 FCTC) prevailed over the national provision, ensuring that the national decree was set aside.

Although in the specific circumstance of this case Article 8.2 FCTC was legally enforceable before the Dutch court, the judgments made no reference to the guidelines and recommendations relating to Article 8.2. In Dutch tobacco case law, as shall be discussed in relation to the second cAn case below, it is interesting that the specific circumstances of the case play a role in deciding whether the treaty provision concerned is legally enforceable.

\section{The Second caN Case: Exemption of the Total Smoking Ban in Lockable, Publicly Accessible Places; Article 8.2 Not Legally Enforceable}

In the second CAN case concerning Article 8.2 FCTC, the Court of First Instance in The Hague was unwilling to grant direct effect to Article 8.2 FCTC. ${ }^{15}$ On 1 January 2015, another governmental decree was adopted which made an exception to the smoking ban for lockable locations in publicly accessible places. This decree was based on Article 10.2.b of the Dutch Tobacco Act, according to which it is legitimate to make an exemption for the smoking ban in publicly accessible places by way of governmental decree.

CAN sued the Dutch government for violating Article 8.2 FCTC by accepting this decree. Again, the questions addressed were whether Article 8.2 FCTC has direct effect in the domestic legal order in the sense of Article 94 of the Dutch Constitution and, if so, whether the measure constitutes a breach of

$14 \quad$ CAN I V. the State [sc], supra note 3, para. 3.6.1.

15 Nederlandse Nietrokersvereniging CAN (Club Actieve Nietrokers) v. De Staat der Nederlanden (Ministerie van Volksgezondheid, Welzijn en Sport), ECLI:NL:RBDHA:2016:11025 (Rechtbank den Haag [Hague Court], 2016), https://www.recht.nl/rechtspraak/uitspraa k/?ecli=ECLI:NL:RBDHA:2016:11025, accessed 20 December 2017 (hereinafter CAN II v. the State) (available only in Dutch). 
Article 8.2 FCTC. Remarkably, in this case, the Court of the Hague answered both questions negatively. ${ }^{16}$ Firstly, the Court stipulated that the intention of Article 8.2 FCTC is not to introduce a total smoking ban in publicly accessible places since in the travaux preparatoires of Article 8.2 FCTC there was no agreement between the FCTC State Parties that the term 'measures' implied a total smoking ban in publicly accessible places. Peculiarly, Principle 1 of the recommendations of the COP concerning Article 8.2 FCTC explicitly includes a total smoking ban in the objective of the Article:

Effective measures to provide protection from exposure to tobacco smoke, as envisioned by Article 8 of the wHo Framework Convention, require the total elimination of smoking and tobacco smoke in a particular space or environment in order to create a $100 \%$ smoke free environment. There is no safe level of exposure to tobacco smoke, and notions such as a threshold value for toxicity from second-hand smoke should be rejected, as they are contradicted by scientific evidence. Approached other than $100 \%$ smoke free environments, including ventilation, air filtration and the use of designated smoking areas (whether with separate ventilation systems or not), have repeatedly been shown to be ineffective and there is conclusive evidence, scientific and otherwise, that engineering approaches do not protect against exposure to tobacco smoke. ${ }^{17}$

In this second CAN case, contrary to the CAN I case, Article 8.2 FCTC was not regarded as an international treaty provision that has direct effect in the sense of Article 94 of the Dutch Constitution. Although the guidelines and recommendations are clear concerning the circumstance that Article 8.2 includes a total smoking ban, The Hague Court did not assess the conformity of the governmental decree of 1 January 2015 with Article 8.2 FCTC and the related guidelines and recommendations. According to the Court, since the guidelines and recommendations are non-binding, the Court does not have the power to review national decrees against these COP guidelines. Furthermore, these guidelines and recommendations go beyond the actual text of Article 8.2 FCTC since, according to The Hague Court, one cannot read a total smoking ban in Article 8.2 FCTC. ${ }^{18}$ Subsequently, the Court stated that a comparison with

\footnotetext{
16 CAN II v. the State, supra note 15, para. 4.

17 Conference of the Parties to the who Framework Convention on Tobacco Control, 'Elaboration of Guidelines for Implementation of the Convention - Article 8', supra note 6, Principle 1.

18 CAN II v. the State, supra note 15, para. 4.10.
} 
the CAN I case could not be made because the circumstances of the CAN II case were 'vitally different'. ${ }^{19}$ According to the Court, the circumstances of the CAN II case differed from the CAN I case because the former concerned an exemption of the Dutch Tobacco Act which was legally binding before the FCTC came into force in the Netherlands. ${ }^{20}$ This reasoning, however, appears to be flawed given that measures that were in place in the Netherlands before 2005 should also be in conformity with the FCTC.

\section{Article 5.3 FCTC in the Netherlands}

\section{Youth Smoking Prevention Foundation: Alleged Close Ties between the Government and the Tobacco Industry; Article 5.3 not Legally Enforceable}

On 8 September 2014, the Youth Smoking Prevention Foundation submitted a civil complaint against the Dutch Government addressing the presumed close ties between the government and the tobacco industry. ${ }^{21}$ The case was based on Article 5.3 FCTC, which requires State Parties to protect their tobacco control and public health policies from commercial and other vested interests of the tobacco industry. ${ }^{22}$ Based on a considerable amount of documents giving evidence of the close and frequent contact between various governmental bodies (including the Ministry of Health) and the tobacco industry, the Foundation argued that the State had failed to comply with several provisions. Among others issues, these documents (made available by virtue of the Dutch Act on Freedom of Information) reflect the following contact between ministries and the tobacco industry.

On 28 September 2010, the Dutch Smoking Tobacco Association, which represents the interests of the fine cut tobacco industry in the Netherlands, sent a letter to the Ministry of Health, Welfare and Sport:

First of all, thank you for your presence at the conference on illegal trade and excise that we organised. We are pleased to see that there is

19 CAN II v. the State, supra note 15 , para. 4.11.

$20 \quad$ CAN II v. the State, supra note 15 , para. 4.12.

21 Complaint submitted by the Youth Smoking Prevention Foundation against the Dutch State, 8 September 2014, available only in Dutch, http://www.stichtingrookpreventiejeugd .nl/wp-content/uploads/2014/o9/o8-09-2014-Dagvaarding-Stichting-Rookpreventie -Jeugd-v.-Staat-der-Nederlanden.pdf, accessed 20 December 2017.

22 Ruth E. Malone and Stella Aguinaga Bialous, 'wно FCтC Article 5·3: Promise but Little Progress', Tobacco Control, 23: 279-28o (2014), p. 279. 
an interest in this topic within various ministries. We appreciate your involvement with our contacts. ${ }^{23}$

On 8 June 2011, the Ministries of Finance, Economic Affairs, and Health, Welfare and Sport visited 'Biggelaar Tabak' (a Dutch tobacco producer). Biggelaar Tabak wrote a letter to the ministries concerned:

Thank you for attending Biggelaar Tabak in Roosendaal today. We are glad that you could find the time to take cognizance of the production process of semi-manufactured tobacco. It was also a pleasure to share some of the concerns that exist among the members of the Association of Dutch Tobacco Industry. At your request, I can send you the PowerPoint presentations used by the speakers. ${ }^{24}$

In the complaint, Article 5.3 FCTC is read in conjunction with the FCTC's guiding principles and recommendations, human rights provisions and the due diligence criteria as grounded in civil law. The Netherlands was one of the key facilitators for the adoption of the guidelines and recommendations that relate specifically to Article 5.3 FCTC. ${ }^{25}$ The complaint submits that these guidelines should be taken into account given their status as 'subsequent agreement between the parties regarding the interpretation of the treaty or the application of its provisions' as stipulated by Article 31 of the Vienna Convention on the Law of Treaties. ${ }^{26}$

The complaint subsequently argues that Article 5.3 FCTC forms an operationalisation of a range of constitutional and human rights provisions, in particular the rights to life and health. ${ }^{27}$ The link between the FСтC and the right to health is firmly established in the Preamble to the FCTC, which explicitly

23 Document 8003, Production 14 of the Complaint (only in Dutch, on file with author).

24 Document 1, Production 14 of the Complaint (only in Dutch, on file with author).

25 Conference of the Parties to the wHo Framework Convention on Tobacco Control, 'Elaboration of Guidelines for implementation of Article 5.3 of the Convention', Doc. FCTC/COP/3/5, Third Session, 17-22 November 2008, http://apps.who.int/gb/fctc/PDF/ cop3/FCTC_COP 3 5-en.pdf, accessed 20 December 2017; Conference of the Parties to the wHo Framework Convention on Tobacco Control, 'Guidelines for Implementation of Article 5.3', supra note 6.

$26 \quad 1969$ Vienna Convention on the Law of Treaties (adopted 23 May 1969; entered into force 27 January 1980), UNTS 1155: 331.

$27 \quad 1950$ Convention for the Protection of Human Rights and Fundamental Freedoms (EC HR) (adopted 4 November 1950; entered into force 3 September 1953), UNTS 213: 221, art. 2; 1966 International Covenant on Civil and Political Rights (ICCPR) (adopted 16 December 1966; entered into force 23 March 1976), UNTS 999: 171, art. 6; International Covenant on 
mentions the right to health in Articles 12 and 24 of the International Covenant on Economic, Social and Cultural Rights (ICESCR) and the Convention on the Rights of the Child (CRC), ${ }^{28}$ respectively. The complaint in the Article 5.3 FCTC case pays considerable attention to the right to health in Article 12 of the ICESCR, thus disregarding the reluctance on the part of the Dutch courts to adjudicate cases on the basis of socio-economic rights. To emphasize the importance of the right to health, the complainant quotes the reference to the right to health in the Preamble of the FCTс. ${ }^{29}$ In this context, the complaint underlines the crucial involvement of governments in the protection of health. ${ }^{30}$

The Court of First Instance in the Hague ruled that Article 5.3 FCTC is insufficiently precise for the Court to rely on in the present case. ${ }^{31}$ In this regard, the Court drew a comparison with (the arguably more precise) Article 8.2 FCTC, which was granted direct effect in the above-mentioned CAN I decision of 10 October 2014. The Court argued that Article 5.3, given its imprecise wording, cannot be seen as a specification of the rights to life and health under the human rights treaties. As such, the Court did not explore the question of whether the evidence provided on the arguably frequent contact between the government and the tobacco industry amounted to a violation of the aforementioned international treaty provisions. This approach reflects the reluctance on the part of Dutch courts to adjudicate cases on the basis of open-ended international norms, ${ }^{32}$ as is also evidenced by the CAN II case discussed above.

Economic, Social and Cultural Rights (ICESCR) (adopted 16 December 1966; entered into force 3 January 1976), UNTS 993: 3 art. 12.

281989 Convention on the Rights of the Child (CRC) (adopted 20 November 1989; entered into force 2 September 1990), UNTS 1577: 3 .

29 Youth Smoking Prevention Foundation Complaint, supra note 21, para. 258.

$30 \quad$ Youth Smoking Prevention Foundation Complaint, supra note 21, para. 257.

31 Stichting Rookpreventie Jeugd $v$. de Staat der Nederlanden, Case No. C/og/475711 / HA ZA 14-1193 (Court of First Instance of the Hague 2015), https://uitspraken.rechtspraak.nl/inz iendocument?id=ECLI:NL:RBDHA:2015:12746, accessed 20 December 2017 (available only in Dutch).

In the Philip Morris case, the Advocate General confirms the impact the FCTC and its Guidelines have on Eu law and policy: ' 75 .... Although this is not apparent from the wording of the Framework Convention itself, it is clear from the Guidelines for Implementation of Articles 9 and 10 which were adopted by the Conference of Parties a few years ago. 76. Whilst those guidelines are not as such legally binding, they do constitute internationally applicable recommendations for implementation of the wHO Framework Convention by its Parties. They therefore also serve as a guide for the EU Member States which concluded that Framework Convention. 77. In these circumstances, the Union legislature could legitimately assume that rules on the use of menthol and other characterising 
A reference to the guidelines and recommendations for the implementation of Article 5.3 is lacking in the judgment.

In response to this case, the Ministry of Health, Welfare and Sport sent a letter and an accompanying document to the Dutch Parliament. ${ }^{33}$ In the accompanying document, the Minister of Health, Welfare and Sport explains that government contact with the tobacco industry should be reduced to a minimum. The document announces a number of further measures to monitor this contact. ${ }^{34}$ Clearly, the case had a spillover effect since it led to a modest change in governmental policy.

\section{Conclusions}

The Netherlands constitute a rare laboratory concerning the legal enforceability of FCTC provisions in the domestic legal order. Due to the moderate

flavours in tobacco products would soon be adopted at national level if uniform provisions were not introduced at Union level. 78. The reason for the fact, highlighted by some of the parties, that in reality hardly any national rules in this regard had been enacted in the EU Member States for a considerable period of time appears to be that the Commission had prepared for and initiated the legislative procedure for the adoption of the contested directive within the $\mathrm{EU}$ at more or less the same time as the wHo Guidelines appeared. 79. Furthermore, the Union legislature could reasonably assume that any national rules to implement the wHo Framework Convention would differ from one Member State to the next and thus lead to the creation of new obstacles to trade in the internal market unless a harmonisation measure was adopted at Union level. Those Guidelines do not stipulate any specific measures for the Parties to the Convention, but accord them extremely broad latitude; in particular, the Guidelines allow them to choose between prohibitions and mere restrictions on the use of flavouring ingredients in tobacco products and only contain examples of such ingredients. 80. Accordingly, the doubts expressed by a number of participating undertakings and by Poland as to the existence of present or future differences between Member States' laws, regulations and administrative provisions are all unfounded'; Philip Morris Brands SARL v. Secretary of State for Health (UK), Case C-547/14, ECLI:EU:C:2015:853 (Court of Justice of the European Union - Opinion of Advocate General Kokott 2015), paras. $75^{-80 .}$

33 Letter to Parliament, clarifying the implementation of 5(3) FCTC, 24 September 2014, https://www.rijksoverheid.nl/documenten/kamerstukken/2015/o9/24/kamerbrief -over-verduidelijking-invulling-artikel-5-3-who-kaderverdrag, accessed 20 December 2017 (available only in Dutch).

34 Dutch Ministry of Health, 'Clarification of Clarification of Interpretation of Article 5.3 wHo Framework Convention', http://www.tabaknee.nl/images/stories/docs/clarification _implementation_art5.3.pdf, accessed 20 December 2017. 
incorporist system in the Netherlands pertaining to the applicability of international law in the national legal order, the FCTC provisions are directly applicable before the Dutch courts. Therefore, Dutch case law pays attention to FCTC provisions.

Two cases addressing Article 8.2 FCTC demonstrate that in Dutch case law the circumstances of the case play a pivotal role in deciding whether the FCTC provision concerned is legally enforceable in the national legal order. In the CAN I case Article 8.2 was considered to be legally enforceable and ensured that a national decree was set aside in respect of Article 8.2 FCTC. However, in CAN II the court judged that due to the different circumstances of the case it was insufficiently clear whether Article 8.2 FCTC implied a total smoking ban. We observe that it is not unthinkable that the outcome of these cases was also different because different courts assessed them; hence, different courts may rely on different lines of reasoning.

In the case concerning the alleged close ties between the Dutch government and the tobacco industry, the court judged that Article 5.3 FCTC was insufficiently unconditional to be legally enforceable in the national legal order. The complainants also brought up several human rights provisions; however, according to the court, Article 5.3 was insufficiently precise to lead to a further specification of these provisions.

The cop's guidelines and recommendations were not used in any of these judgments to interpret the relevant FCTC provisions. They were not considered to form part of the FCTC and thus were considered judicially non-binding. These recommendations and guidelines are aimed at concretizing the objective(s) and goal(s) of the concerned FCTC provisions, and moreover at assisting State Parties in meeting their obligations under Articles 8.2 and 5.3. It is, therefore, regrettable that these standards were not taken into account. In other jurisdictions, however, there are cases where the cop's guidelines and recommendations have been taken into account. For instance, in the case between British American Tobacco Colombia and Coljuegos, ${ }^{35}$ which concerned a prohibition on tobacco companies that use promotional strategies, the Guidelines for the implementation of Article 13 FCTC are taken into account. Moreover, in the decision, it is stated that FCTC State Parties approved the guidelines to Article 13 FСтC, which entails that these guidelines form a useful tool when interpreting the article. In addition, in this judgment, the guidelines are qualified as a subsequent agreement in accordance with the Vienna Convention on the Law of Treaties. In the case between British American Tobacco UK and the Secretary of State for Health, FCTC guidelines were also taken into account: 
In particular, the Government relied upon the fact that in the FCTC contracting States were under obligations to meet the treaty objective to reduce continually and substantially the prevalence of tobacco use and exposure to tobacco smoke through the implementation of 'comprehensive tobacco control strategies'. The Government stated that since it became a party to the treaty in 2004 it had taken its international obligations very seriously. The Government recognised that the FCTC guidelines were not binding. However, the fact that the contracting parties had agreed that the guidelines reflected their 'consolidated view of a desirable means of fulfilling their FCTC obligations' was important. ${ }^{36}$

It is important to note, however, although the Dutch Courts do not take into account the FCTC guidelines, the body of Dutch case law concerning tobacco control contributed considerably to an increasing debate in Dutch society about smoking bans and the ties between government and the tobacco industry. ${ }^{37}$ This increasing debate has so far resulted, in addition to other steps, in the gradual adoption of new measures to further reduce tobacco use, ${ }^{38}$ and a commitment in the new Dutch governmental agreement to embrace the tobacco-free generation and to increase tobacco-related taxes. ${ }^{39}$

\section{Note}

The manuscript was submitted on 20 December 2017. Developments after this date are not included.

36 British American Tobacco United Kingdom v. Secretary of State for Health, supra note 4, para. 146.

37 E.g. Marc Chavannes, 'Roken is hier een keurig aangeharkt massagraf [Smoking in the Netherlands is a Neatly Raked Mass Grave]', NRC Handelsblad, 19 July 2015.

38 Dutch Government, 'Roken ontmoedigen door nieuwe regels', https://www.rijksoverheid .nl/onderwerpen/roken/roken-ontmoedigen, accessed 20 December 2017 (available only in Dutch).

39 Tweede Kamer der Staten generaal, 'Regeerakkoord', https://www.tweedekamer .nl/zo_werkt_de_kamer/verkiezingen_en_kabinetsformatie/regeerakkoord, accessed 20 December 2017 (available only in Dutch). 